\title{
THE DEVELOPMENT OF THE EMBRYO SAC IN THE CONVALLARIACEAE
}

F. MCALLISTER

\section{(WITH PLATES VI AND VII)}

The family Convallariaceae as used by Britton (2) is the equivalent of the family Asparagoideae as it is used by ENGLER and Prantl (12). Gray's New manual (20) has not made use of either of the above family names, but has distributed the ro genera occurring within the family in the tribes Polygonateae and Parideae. In this paper I shall refer to this group of genera as the Convallariaceae.

Of the ro genera of the Convallariaceae occurring in the northeastern part of the United States, Clintonia has been investigated by SMith (23), Convallaria by WiEgand (24), Trillium grandiflorum by ERNST (13), and T. recurvatum by Coulter and ChamBERLAIN (II). I have in earlier papers reported on Smilacina stellata (18) and S. racemosa (19), and in this paper report my investigations on Maianthemum, Streptopus, Polygonatum, and Medeola. The only genera occurring within this range which have thus far not been reported upon are Asparagus and Disporum.

Much of this work on the Convallariaceae was carried on at Beloit College during the years 1907 and 1908. Material for the study of Smilacina stellata, S. racemosa, Polygonatum commutatum, and Maianthemum canadense were collected in the vicinity of Beloit, Wisconsin. Professor W. J. V. Osterhout kindly supplied me with fixed material of Smilacina sessifolia from the vicinity of Berkeley, California, and Professor H. D. Densmore very generously turned over to me considerable material of Smilacina amplexicaulis which he had collected and fixed in California. I am indebted to Mr. R. E. Webster for material of Clintonia borealis from the vicinity of Iron Mountain, Michigan. Flowers of Streptopus roseus and Medeola virginica were collected and fixed in the vicinity of Ithaca, New York, in the spring of rgr 2.

[Botanical Gazette, vol. 58 
The publication of these results has been delayed from time to time, partly owing to the press of other work and partly through the hope of including other members of the group in this report.

I have reviewed in another connection (18) the scanty literature on the development of the embryo sac among members of the Convallariaceae. Two accounts of the development of the embryo sac of Convallaria majalis differ radically as to the fate of the first four nuclei resulting from the division of the nucleus of the mother cell. According to WIEGAND's account (24), all 4 of these nuclei enter into the structure of the mature embryo sac, while SCHNIEWIND-Thies (2I) reports that but one of 4 megaspores enters into the structure of the embryo sac.

ERNST (13) reports that in Trillium grandiflorum the inner of the 2 cells resulting from the heterotypic division develops into the embryo sac, while Chamberlain (9) finds that in Trillium recurvatum the inner of 4 megaspores develops into the embryo sac. ERNST (13) also found that in Paris quadrifolia the inner of the first 2 cells arising from the first division of the mother cell formed the mature embryo sac by three divisions of its nucleus, as was the case in Trillium grandiflorum.

In the paper referred to above (18) I have shown that in Smilacina stellata the megaspore mother cell divides to form 4 fully separated megaspores, and that the separating membranes later disappear, forming thus a tetranucleate cell, from which, by one division of its 4 nuclei, the mature embryo sac is formed.

Since the publication of the above-mentioned paper, one other member of the family has been reported upon. According to Sмiтн (23); the reduction divisions of the megaspore mother cell of Clintonia borealis result in the formation of a tetranucleate cell, the outermost nucleus of which is plump and normal, while the remaining 3 inner nuclei are shrunken and disorganized. The outermost nucleus divides twice, and 3 of the resulting 4 nuclei organize an apparently normal egg apparatus, while the remaining nucleus serves as the single polar nucleus. I have been able to confirm Smith's results from material collected in the vicinity of Iron Mountain, Michigan, a few sections of which I had already prepared at the time of the publication of his results. 
My work on the embryo sac of Smilacina racemosa (19) has shown that in closely related species of the same genus a marked difference may exist in the origin of the nuclei entering into the structure of the embryo sac. In $S$. racemosa the mother cell divides unequally, forming a large outer and a small inner cell. Later stages show the division membrane to be permanent. From the outer cell the 8 nuclei of the mature embryo sac are formed by three divisions. Split cell membranes separate for a short time the two pairs of nuclei resulting from the division of the heterotypic daughter nuclei (figs. 28, 29). The nucleus of the small inner cell divides but once, and the 2 resulting nuclei gradually degenerate. The embryo sac in $S$. racemosa is thus formed from the 2 outer of the 4 potential megaspores. S. stellata (I8), on the other hand, forms its embryo sac from 4 megaspores which become merged in one 4-nucleate cell by the disappearance of the partition membranes.

\section{Smilacina sessifolia}

As cited above, the embryo sac of $S$. stellata is formed from 4 fully separated megaspores which become merged in one cell, one further division of the 4 nuclei forming the 8-nucleate embryo sac (figs. 26, 27). Three divisions of the nucleus of the megaspore mother cell thus produce the necessary number of nuclei for the mature embryo sac, as in cases of the so-called Lilium type of embryo sac formation.

I have found that in $S$. sessifolia the 4 nuclei resulting from the first two divisions of the megaspore mother cell are at first separated by cell membranes, and later, owing to the disappearance of the membranes, come to occupy a large common cell precisely as in S. stellata.

Fig. 3 shows the 4 cells arranged bilaterally, while in fig. 4 a linear row of 4 is to be seen. The bilateral arrangement here is much the more abundant. The cell membranes of the second division, as is the case in $S$. stellata, are the first to disappear (fig. 5), forming thus 2 binucleate cells. Later the middle membrane disappears, giving rise to a tetranucleate cell (fig. 6). This 
cell enlarges rapidly by vacuolization (fig. 7) and its nuclei undergo another division to form the 8-nucleate embryo sac (fig. 8).

\section{Smilacina amplexicaulis}

I have also in an earlier paper (I9) referred to the apparent identity of the embryo sac development in $S$. racemosa with that of $S$. amplexicaulis. A more careful examination of the first two divisions of the megaspore mother cell of the latter species confirms these earlier observations.

The megaspore mother cell of $S$. amplexicaulis may be hypodermal (fig. II), or it may be one or two cell layers beneath the epidermis. Fig. I3 illustrates the unequal first division of the mother cell to form a large outer cell and a small inner one. A cell plate is formed which splits, causing the complete separation of these 2 cells. Later phases show this separation to be permanent. These heterotypic daughter nuclei divide simultaneously, and conspicuous cell plates are formed (figs. I4, I5), but I have never observed the splitting of the membranes as is the case in $S$. racemosa. In the latter species the complete separation of these homoeotypic nuclei seemed to be of short duration, and it is probable that more abundant material would show that in the case of $S$. amplexicaulis complete membranes are also formed, which, however, disappear early to form the 2 unequal binucleate cells (fig. I6).

Because of scarcity of material, I have been unable to follow the development of this embryo sac farther than the 4-celled stage. The close similarity of the two species ( $S$. amplexicaulis being the Pacific Coast form of $S$. racemosa) makes it very probable that the embryo sac development is identical in the two species.

\section{Maianthemum canadense}

In Maianthemum canadense the first division of the nucleus of the megaspore mother cell is followed by the formation of a cell membrane which separates the 2 resulting nuclei (fig. I9). Similar membranes are formed separating the homoeotypic nuclei, so that 4 fully separated cells result (figs. 20, 2I), as is the case in Smilacina stellata and S.. sessifolia. As is shown in figs. I9-2 I, the 4 resulting megaspores are rarely arranged in an axial row, but 
are usually arranged more or less bilaterally. Although I was not able to identify split cell membranes between these reduction nuclei, the cell plates are nevertheless very different from "evanescent cell plates" such as are to be seen, for example, in the first divisions in the developing embryo sac of Lilium. In Maianthemum the cell membrane extends out and joins with the lateral wall of the mother cell, while all traces of the central spindle disappear. Later the partition membranes degenerate, thus giving rise to a tetranucleate cell (fig. 22). This tetranucleate cell enlarges by the formation of vacuoles in its interior (figs. 23, 24), and its nuclei undergo a further division to form the 8-nucleate embryo sac (fig. 25).

\section{Streptopus roseus}

The first division of the megaspore mother cell of Streptopus roseus results in the formation of 2 equal and fully separated daughter cells (fig. 30). The inner cell enlarges, gradually compressing the outer into a disorganized crescent-shaped mass (fig. $3 \mathrm{I}$ ).

Before the outer cell has been completely disorganized, the inner daughter cell divides, forming, in some cases at least, 2 fully separated daughter cells (fig. 32). In most cases, however, the partition wall is lacking, either not having been formed or having degenerated after formation (fig. 35). It is of course impossible to determine whether a partition wall is formed in all cases, but since the evidence is clear that it is frequently formed, it seems reasonable to expect that it is formed in all cases and subsequently undergoes degeneration.

Widely separated daughter cells such as are illustrated in fig. .33 are occasionally to be seen. While this wide cleft between the cells is in this case, without doubt, due to plasmolysis, such a wide separation could of course not have taken place had not the 2 cells been perfectly distinct. Whether 2 such widely separated cells can fuse to form a single binucleate cell may be doubted. Further evidence on this point is to be seen in fig. 34. Here the nuclei of 2 homoeotypic daughter cells have each divided, forming 2 distinct binucleate cells. The disorganized mass at the micropylar end of the outer cell is the remains of the outer cell of the first division. A tendency is thus shown toward the formation of an embryo sac 
from each of the potential megaspores arising from the inner heterotypic daughter cell.

The binucleate cell arising from the homoeotypic division in the inner (heterotypic) daughter cell enlarges greatly by vacuolization, and by two further nuclear divisions forms the 8-nucleate embryo sac (figs. 36, 37). After a period of growth, a typical egg apparatus and an antipodal group are organized. The polar nuclei fuse and the fusion nucleus takes up a position close to the egg.

\section{Medeola virginica}

The very large megaspore mother cell of Medeola virginica is in many cases hypodermal. Fig. 38 shows a very common condition in which the mother cell in synapsis lies in contact with the epidermis.

Although a conspicuous cell plate is formed at the time of the first division of the nucleus of the mother cell (fig. 39), it does not, so far as I can determine, result in the formation of a division membrane. It entirely disappears before the homoeotypic division.

The outer heterotypic nucleus divides slightly in advance of the inner, and temporary cell plates are formed between each pair of nuclei (fig. 40). These cell plates persist for some time, often being visible after the third division of the mother cell (fig. 43).

The daughter nuclei resulting from the division of the inner heterotypic nucleus may be equal in size (fig. 40) or they may be very unequal (fig. 4I), the innermost nucleus being much smaller than the outer. In several cases, in fact, the inner nucleus appeared so shrunken and disorganized as to be very probably incapable of further division (fig. 42). Such a condition would cause embryo sacs with but 2 antipodal cells, and it seems very probable that this is occasionally the case.

Frequently the small inner nucleus divides at the time of the division of its larger sister nucleus, the result being 2 large and 2 small nuclei. One of the large nuclei is a polar nucleus, and the other, with the 2 small nuclei, forms the 3 antipodal nuclei (fig. 43). In still other cases, where the division of the inner heterotypic nucleus has been such as to form 2 nuclei of equal size, 3 uniform antipodal nuclei are formed (fig. 44). 
A normal egg apparatus is formed from the 3 micropylar nuclei. In other respects as well the embryo sac seems normal.

\section{Polygonatum commutatum}

In Polygonatum commutatum the megaspore mother cell is frequently hypodermal (fig. 45), or it may be separated from the epidermis by one or two layers of cells (fig. 46). The mother cell divides twice to form an axial row of 4 permanently separated megaspores (figs. 47, 48). The inner spore enlarges by vacuolization, while the outer 3 gradually shrivel and disorganize (fig. 49). Three divisions of the nucleus of this functional megaspore form the 8 nuclei of the mature embryo sac (figs. 50, 51, 52): A normal embryo sac is organized from the 8 nuclei thus formed. The 2 polar nuclei fuse early, and the fusion nucleus lies in close proximity to the antipodal cells until immediately before fertilization, when it takes up a position near the egg.

This mode of embryo sac development has been called the "normal" as contrasted with the "lily type" of development. It seems clear, especially from the embryo sac behavior in the Convallariaceae, that no one type of development can be regarded as "normal."

I have shown that in the cases of Smilacina stellata and $S$. racemosa $(\mathbf{1} 8, \mathbf{1 9})$ reduction in the number of the chromosomes takes place with the first two divisions of the megaspore mother cells. While I have been unable to make reliable countings of the chromosomes in the case of the other species studied, I have found evidences of the reduction divisions, such as the synapsis stage and double heterotypic chromosomes, in all the forms investigated, with the exception of Streptopus roseus, in which I was unfortunately unable to get the first division of the mother cell. In view of the indirect evidence mentioned above, it seems safe to conclude that, as with Smilacina stellata and $S$. racemosa, reduction in the chromosome number accompanies the first two divisions of the mother cell in the members of the group which I have studied. In Clintonia (23), Trillium (I I, I3), and Paris (13), the evidence shows clearly that the first two divisions of the megaspore mother cells are reduction divisions. 


\section{Two megaspore mother cells}

Among the monocotyledonous plants, 2 megaspore mother cells in the same nucellus have been reported in but few instances. In Ornithogalum pyrenacium, GUIGNARD (i5) reports that 2 large cells ("deux grosses cellules collaterales") are often present at the apex of the nucellus. BERNARD (I) has reported 2 embryo sacs in Lilium candidum in the same nucellus. Coulter and CHamberlaIN (II) report two cases in Lilium philadelphicum, in one of which 3 "archesporial cells" were present in the same nucellus and in the other 5. Miss Ferguson (14) has called attention to a single case of the occurrence of 2 mother cells separated by a layer of somatic cells in a single megasporangium of Lilium longiflorum. LECHMERE has also reported (16) for Fritillaria messanensis 2 embryo sacs which apparently have arisen from distinct mother cells side by side in a single ovule.

In the genus Smilacina 2 megaspore mother cells or their derivatives occur occasionally in the same nucellus. In S. stellata I have observed in four different cases 2 partially developed embryo sacs in the same nucellus, separated by somatic tissue (fig. 10). There can be no doubt that these have arisen from distinct mother cells. In $S$. sessifolia 2 mother cells were frequent. On one raceme, approximately one nucellus out of 4 contained either 2 mother cells or 2 developing embryo sacs. As is shown in fig. 9 , they are usually separated more or less by somatic cells. In S. racemosa 2 mother cells or embryo sacs were in several cases observed lying side by side in the same nucellus, in some instances lying in contact and in others separated by sterile cells. In $S$. amplexicaulis 2 mother cells in the same ovule were observed on several occasions. While a complete record was not kept of all preparations showing this, I have records of five such abnormalities. As is shown in fig. 12, they. are usually separated more or less by somatic cells.

In Polygonatum commutatum 2 mother cells in one megasporangium were occasionally observed (fig. 45). Four such cases have been recorded but others were observed. In Maianthemum canadense three cases were also observed of 2 megaspore mother cells in the same nucellus. As will be seen from fig. I7, the nucellus is abnormally broad and the mother cells are partially separated by disintegrating somatic cells. 
It is probable that little significance is to be attached to these abnormalities. The occurrence of more than one megaspore mother cell in a nucellus is common in the dicotyledonous plants, and it has been rather remarkable that more have not been found among the monocotyledons.

As will be seen from figs. I , I2, I7, and I8, the ovules in which 2 mother cells or 2 embryo sacs have been figured are all conspicuously broader than those containing but one mother cell. The relative proportion of the sterile tissue in the two cases is essentially the same, thus suggesting that where a normal amount of sterile tissue is present but one mother cell is formed.

\section{Discussion}

It will be seen from the foregoing that within the limits of the Convallariaceae considerable variation exists as to the origin of the embryo sac. In Polygonatum commutatum and in Trillium recurvatum (9) the embryo sac arises from one of an axial row of 4 megaspores. In Clintonia borealis (23) it arises from the outer of 4 megaspore nuclei, which are, however, not separated by cell walls or membranes. In Smilacina racemosa and in $S$. amplexicaulis it has its origin from the outer daughter cell of the first division of the mother cell; while in Streptopus roseus, Trillium grandiflorum (13), and Paris quadrifolia (13) the embryo sac arises from the corresponding inner daughter cell. In Smilacina stellata, S. sessifolia, and Maianthemum canadense 4 fully separated megaspores, by the disappearance of the partition walls, become merged in one tetranucleate cell. One division of each of these 4 nuclei forms the 8 nuclei of the complete embryo sac. The immature embryo sac of Convallaria majalis, according to WIEGAND (24), has a single cell membrane separating the inner pair of reduction nuclei from the outer pair, and in Medeola virginica a pronounced cell plate is developed between the daughter nuclei of the first division of the mother cell; which, however, disappears before the second division, and definite though temporary cell plates are also formed between the homoeotypic nuclei. Thus it will be seen that in this group, one, two, or four of the reduction nuclei may enter into the structure of the mature embryo sac. 
In those forms in which more than one reduction nucleus enters into the structure of the embryo sac, we find various degrees of separation of these nuclei in temporary cells. In Smilacina stellata and $S$. sessifolia and in Maianthemum canadense the 4 reduction nuclei become fully separated by cell membranes, which later disappear. In Smilacina racemosa, whose embryo sac arises from the outer of 2 daughter cells, the homoeotypic nuclei are for a time fully separated from one another by split cell plates. In S. amplexicaulis definite cell plates are present between these homoeotypic nuclei, and it seems probable that an examination of sufficient material would show the splitting of these cell plates. In Streptopus roseus, whose embryo sac arises from the inner daughter cell of the first division, a definite cell plate is formed which, at times at least, splits, thus causing complete separation of the 2 homoeotypic nuclei. The single cell membrane in the developing embryo sac of Convallaria majalis (24) and the cell plates in Medeola show the tendency here toward the separation of the products of the reduction divisions into distinct cells.

There seems to be substantial agreement that in cases where one cell of an axial row of 4 develops into the embryo sac, the 4 cells are to be regarded as megaspores, and the cell from which these have arisen a megaspore mother cell. Both megaspore mother cell and megaspore are regarded as the morphological equivalents of the microspore mother cell and microspore respectively. In those cases, however, in which the embryo sac develops from one of the 2 daughter cells of the megaspore mother cell or from the undivided megaspore mother cell, in general two opposing views are prevalent. The one, elaborated by Coulter (Io), regards reduction as a criterion by which spores or spore nuclei may be identified, and holds that even though the reduction nuclei are not separated they should nevertheless be regarded as megaspore nuclei. The other view, probably most actively supported by CAMPBELL $(6,7)$ and BROWN $(3,4)$, holds that reduction is not the "sole criterion" for distinguishing spores and gametophytes, and that the cell giving rise to the embryo sac should be regarded as a megaspore, whether it is the undivided megaspore mother cell, one of 2 daughter cells, or one of 4 daughter cells. 
It seems clear that these two views are due to a difference in the usage of the terms "megaspore mother cell" and "megaspore," rather than to any misunderstanding or misinterpretation of the data. That the megaspore mother cell of Lilium has a function similar to that of the inner megaspore of the row of 4 in Polygonatum may be the case, inasmuch as both give rise to the embryo sac, but the mother cell in the first case has arisen from the tissue of the nucellus, in the same position and by almost identical cell divisions as in Polygonatum. Aside even from any consideration of the reduction phenomena, there would seem to be no doubt as to the strict homology of the megaspore mother cells in these two forms on the basis of their position in the nucellus, their conspicuous size, the character of their protoplasm, and the mode of their differentiation from the tissue of the nucellus. This conclusion applies equally well to the megaspore mother cells of most other angiosperms. The fact that the heterotypic division occurs in the megaspore mother cell of Lilium may be regarded as confirmatory evidence of its nature.

The first 4 nuclei of the lily embryo sac originate, also, by steps identical with those giving rise to the nuclei of the megaspores. of Polygonatum. These 4 nuclei in the above-mentioned two forms are homologous, whether we call them "megaspore nuclei" or "the first 4 nuclei of the embryo sac." The increasing number of cases in which the first 4 nuclei arising from the megaspore mother cell are found to be more or less separated by temporary cell membranes suggests very strongly that the conditions in Lilium have arisen in a like manner, namely the loss by the 4 megaspores of their physiological individuality as spores and the subsequent disappearance of the separating membranes to form the 4-nucleate stage of the embryo sac.

In Smilacina stellata (18) I have shown that the 4 reduction nuclei are completely separated, the cell plate having split so that wide clefts between the cells are often present. This separation is due probably to shrinkage in fixation. The cell membranes cannot be regarded in the same light as evanescent cell plates, for here the cell plates are completely formed, after which they split to form the distinct membranes of the new cells. There can be no 
doubt as to the individuality of the 4 cells, and that they are the morphological equivalents of megaspores is beyond question.

In Smilacina racemosa (19), although but the 2 outer reduction nuclei enter into the structure of the embryo sac, they too are for a time fully separated by a split cell plate.

In Streptopus roseus, also, the cell plate which separates the 2 homoeotypic nuclei entering into the structure of the embryo sac very often splits, thus causing a complete separation of these 2 nuclei. I have referred above to evidence which suggests that at times this separation may be permanent.

No other conclusion seems possible than that 4 fully separated cells arising from a megaspore mother cell by the reduction divisions must be megaspores. That the 2 cells which in Smilacina racemosa and in Streptopus roseus fuse to form the 2-celled stage of the embryo sac are also megaspores seems equally clear.

The cell membranes separating the reduction nuclei in the megasporangia of Smilacina sessifolia, S. amplexicaulis, and Maianthemum canadense, although in my material showing no splitting into two distinct cell walls, are nevertheless much more complete and persistent than the evanescent cell plates such as have been reported at times for the embryo sac of Lilium and in other genera. These membranes extend out and join the lateral walls and all traces of a central spindle disappear. It seems, very possible that an examination of sufficient stages would show that these membranes also split as is the case in Smilacina stellata.

The transition from forms like the foregoing, in which the division membranes persist for some time, to the lily type of embryo sac is strongly suggested by those forms in which the membranes are incomplete and evanescent, as is the case in Medeola and Clintonia. Additional evidence on this point has been contributed by Brown and Sharp for Epipactis (5). According to their account, although the embryo sac usually arises from the inner of an axial row of 4 megaspores, it also frequently arises from the megaspore mother cell, evanescent cell membranes being formed, and it may possibly be formed from the 2 inner megaspores. Evidence on this latter point, however, was not conclusive. 
The cell plates or membranes in the embryo sac of Medeola and of Epipactis are simply more fully formed and more persistent than those of Lilium, and a little less fully formed and less enduring than those of Smilacina and Maianthemum. The question as to the relative completeness and duration of the membranes separating the reduction nuclei in these forms is one that cannot affect the homology of the cells in question. They are all morphologically megaspores. That those reduction nuclei which are not even separated by evanescent cell plates, if such exist, are also to be regarded as megaspore nuclei would seem, on the basis of their homology with the above-mentioned forms, to be an unavoidable conclusion.

The presence or absence of temporary or evanescent cell plates between the reduction nuclei as a means of determining whether the mother cell is to be regarded as a megaspore or whether each of the reduction nuclei is to be regarded as the nucleus of a megaspore (4) seems in the light of the above evidence to be not only "inconclusive" but worthless. I have shown that the presence even of split cell membranes is no indication that such membranes will be permanent, while, on the other hand, the lack of division membranes between the reduction nuclei does not necessarily result in the lily type of embryo sac formation. In the cases of Eichhornia (22), Avena (8), Crucianella (I7), and Asperula (I7), although division membranes are lacking, nevertheless the functional megaspores develop exactly as though such membranes were present. In Crucianella all 4 megaspores may germinate, though ultimately but one embryo sac matures while the other 3 degenerate. If the lack of cell plates or membranes between the reduction nuclei really signified that the reduction divisions have been shifted so that they occur in the embryo sac, we should have upon the division of the homoeotypic nuclei in Crucianella an 8-nucleate embryo sac. Subsequent development shows, however, that we really have 4 embryo sacs "in tandem."

\section{Summary}

I. In the eight members of the Convallariaceae investigated by the author, the embryo sac is formed from one reduction nucleus 
in Polygonatum, from 2 in Smilacina racemosa, S. amplexicaulis, and Streptopus roseus, and from 4 in Smilacina stellata, S. sessifolia, Maianthemum canadense, and Medeola virginica.

2. In all forms in which more than one reduction nucleus enters into the structure of the embryo sac, these nuclei are at first more or less completely separated by cell membranes, the degree of separation varying from split cell plates in Smilacina stellata to evanescent cell plates in Medeola virginica.

3. The difference in the degree of the separation of these cells cannot affect their morphological status; they are all megaspores.

4. In the light of this evidence it seems reasonable to conclude that all reduction nuclei arising from the nucleus of the megaspore mother cell, whether temporarily separated or not separated at all, should be regarded as megaspore nuclei.

5. Two megaspore mother cells were occasionally observed in six of the eight species investigated.

UNIVERSITy OF TEXAS

Austin, Texas

\section{LITERATURE CITED}

I. BERNARD, C. H., Recherches sur les sphères attractives chez Lilium candidum, etc. Jour. Botanique $14: \mathrm{II} 8-\mathrm{I} 24, \mathrm{I} 77-\mathrm{I} 88,206-2 \mathrm{I} 2$. I900.

2. Britton, Nathaniel LoRD, Manual of the flora of the northern states and Canada. New York. rgor.

3. Brown, William H., The nature of the embryo sac of Peperomia. Bot. GAz. 46:445-460. I908.

4. - - The embryo sac of Habenaria. Bot. Gaz. 48:24I-250. I909.

5. Brown, William H., and Sharp, Lester W., The embryo sac of Epipactis. Вот. Gaz. 52:439-452. I9II.

6. Campbell, D. H., The embryo sac of Pandanus. Bull. Torr. Bot. Club 36:205-220. 1909.

7. - - The embryo sac of Pandanus. Ann. Botany 25:773-789. I9II.

8. CANnon, W. A., A morphological study of the flower and embryo of the wild oat, Avena fatua. Proc. Calif. Acad. Sci. III. I:329-364. I900.

9. Chamberlain, C. J., Winter characteristics of certain sporangia. Вот. GAZ. 25: I24-I 28. I898.

ro. Coulter, J. M., Relation of megaspores to embryo sacs in angiosperms. Bот. GAZ. 45:36I-366. I908.

II. Coulter, J. M., and Chamberlain, C. J., Morphology of the angiosperms. New York. 1903. 
I2. Engler, A., and Prantr, K., Die natürlichen Pflanzenfamilien. II. Teil. 5. Abteilung. I888.

13. ERNST, A., Chromosomenreduktion, Entwicklung des Embryosackes, und Befruchtung bei Paris quadrifolia und Trillium grandiflorum. Flora 9r: I-46. I902.

14. Ferguson, Margaret C., Two embryo sac mother cells in Lilium longiflorum. Bот. GAz. 43:4I8-4I9. I907.

15. Guignard, L., Recherches sur le sac embryonnaire des Phanérogames Angiospermes. Ann. Sci. Nat. Bot. VI. I3: I36-I99. I882.

r6. Lechmere, A. E., Two embryo sac mother cells in the ovule of Fritillaria. New Phytologist 9:257-259. I9I0.

I7. Lloyd, F. E., The comparative embryology of the Rubiaceae. Mem. Torr. Bot. Club 8:27-II2. I9O2.

18. MCAldister, F, The development of the embryo sac of Smilacina stellata. Bот. GAZ. 48:200-2 I5. I909.

19. - - On the cytology and embryology of Smilacina racemosa. Trans. Wis. Acad. Sci. 17: 599-660. I9r3.

20. Robinson, B. L., and Fernald, M. L., Gray's new manual of Botany. Seventh edition. New York. r9o8.

2r. Schniewind-Thies, J., Die Reduktion der Chromosomenzahl und die ihr folgenden Kerntheilungen in den Embryosackmutterzellen der Angiospermen. Jena. rgor.

22. Smith, Wilson R., A contribution to the life history of the Pontederiaceae. Вот. GAZ. 25:324-337. I898.

23. - - The tetranucleate embryo sac of Clintonia. Bот. Gaz. 52:2092I7. I9II.

24. Wiegand, K. M., The development of the embryo sac in some monocotyledonous plants. Вот. GAz. 30:25-47. I900.

\section{EXPLANATION OF PLATES VI and VII}

All the figures were made with the aid of a camera lucida and reduced one-third. The magnification (reduced) is about 400, with the exception of fig. 38 , which has a magnification of 200 . Unless otherwise indicated, the micropyle is down in the figures.

\section{Smilacina sessifolia}

FIG. I.-Embryo sac mother cell recovering from synapsis.

FIG. 2.-First division of megaspore mother cell.

FIG. 3.-Four fully separated megaspores arranged bilaterally.

FIG. 4.-Four fully separated megaspores in an axial row.

FIG. 5.-The membranes of the homoeotypic division have disappeared, leaving only the membrane of the first division.

FIG. 6.-No traces of membranes remain; the 4-nucleate stage of the embryo sac. 
FIG. 7.-A slightly older embryo sac.

Fig. 8.-An 8-nucleate embryo sac.

Fig. 9.-Two immature embryo sacs in the same nucellus.

\section{Smilacina stellata}

FIG. I0.-Cross-section of nucellus showing 2 megaspore mother cells.

\section{Smilacina amplexicaulis}

FIG. I I.-Mother cell hypodermal, in synapsis.

FIG. I2.-Two mother cells in synaptic stage in the same nucellus.

FIG. 13. - The unequal first division of the mother cell.

FIG. I4.- The second division of the mother cell; the cells of the first division completely separated.

Fig. 15.-Second division; cell plates between the homoeotypic nuclei.

FIG. 16.-The 4 reduction nuclei are now contained in 2 binucleate cells; the inner pair of nuclei are degenerating, while the outer pair, from which the embryo sac develops, are plump and normal.

\section{Mianthemum canadense}

FIG. I7.-Two megaspore mother cells in synaptic condition.

FIG. I8.-A single megaspore mother cell.

FIG. I9.-The first division of the megaspore mother cell.

FIG. 20.-Four fully separated cells arising from the megaspore mother cell; the arrangement of the 4 cells very irregular.

FIG. 21.-A similar stage, showing again 4 fully separated cells.

FIG. 22.-A later stage in which the cell membranes separating the cells have disappeared, causing the 4-nucleate stage of the embryo sac.

FIGs. 23, 24.-Stages in the vacuolization of the tetranucleate embryo sac.

FIG. 25.-An immature 8-nucleate embryo sac.

\section{Smilacina stellata}

FIG. 26.-Four megaspores fully separated by split cell plates.

FIG. 27. - The cell membranes of the second division have disappeared, but the split cell plate of the first division still persists.

\section{Smilacina racemosa}

Fig. 28.-Four unequal megaspores fully separated by split cell plates.

FIG. 29.-A slightly later stage than the above, in which the cell membranes of the second division are disappearing; the inner pair of nuclei are no longer separated, while but a small part of the cell plate persists between the outer pair.

\section{Streptopus roseus}

FIg. 30.-Two fully separated daughter cells arising from the megaspore mother cell.

FIG. 3I.-The inner daughter cell is enlarging at the expense of the outer. 

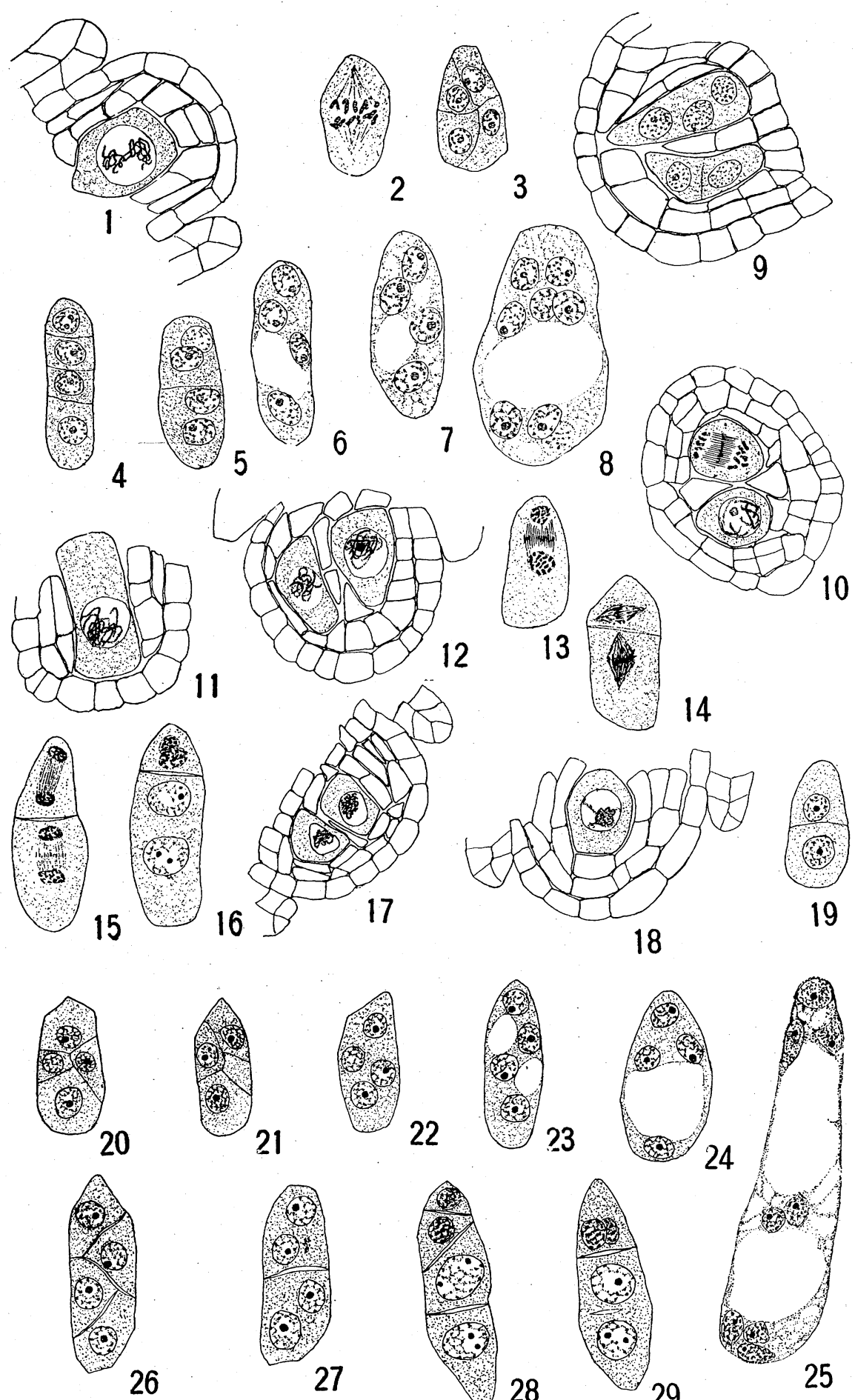

This content downloaded from 071.213.084.080 on February 19, 2018 18:50:54 PM

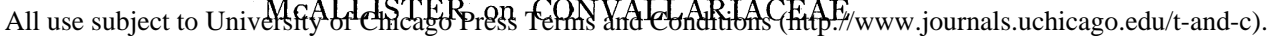




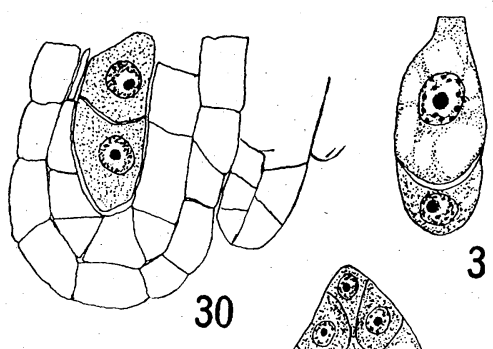

31
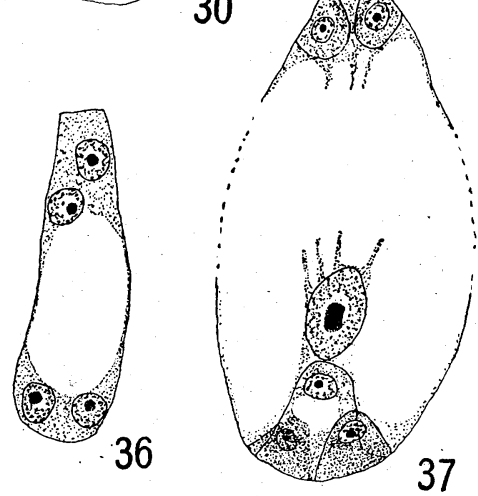

35
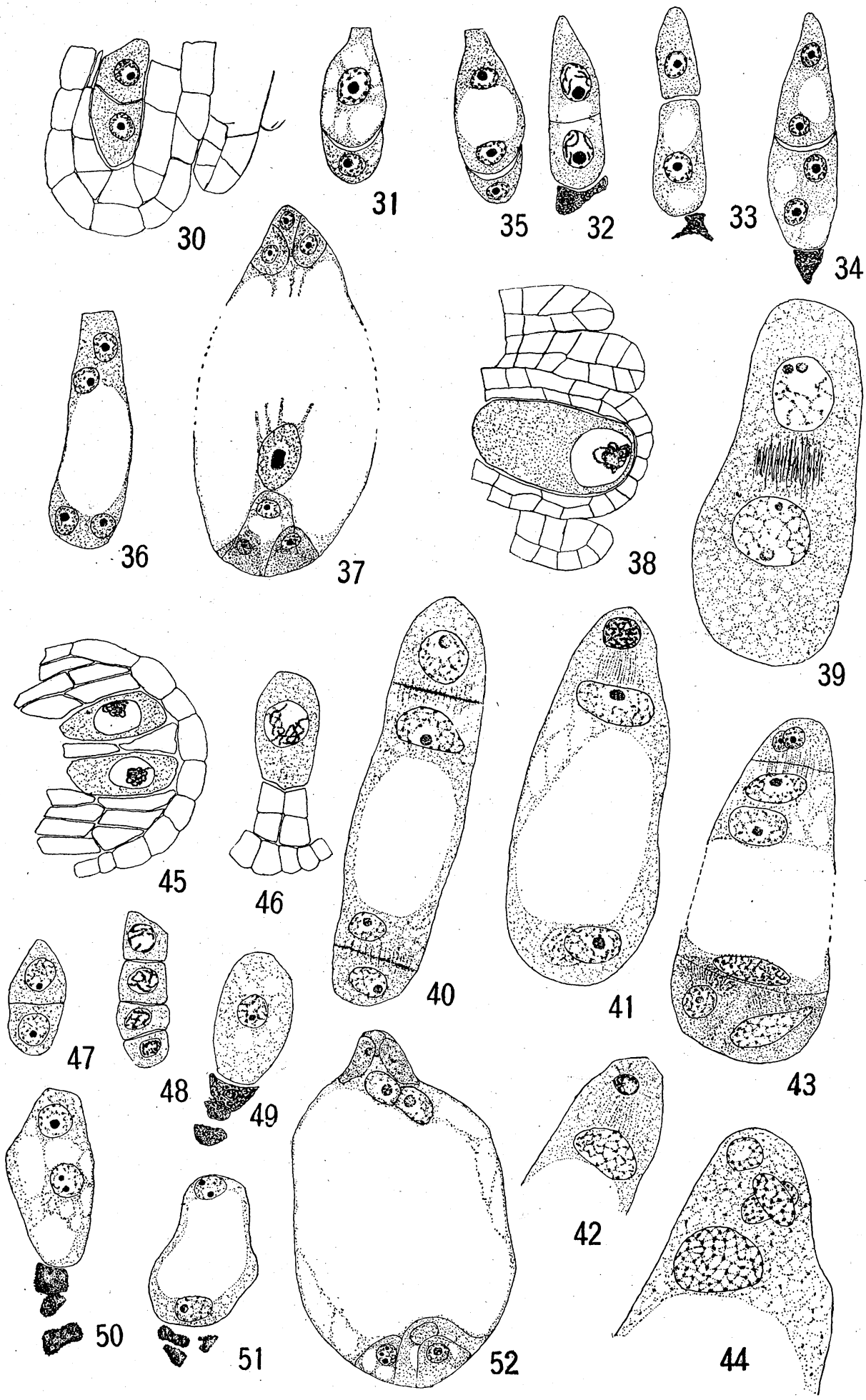

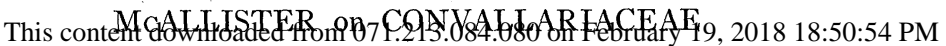

All use subject to University of Chicago Press Terms and Conditions (http://www.journals.uchicago.edu/t-and-c). 
FIG. 32.- The inner daughter cell has divided to form 2 cells which are separated by a definite and complete cell plate; the outer daughter cell now but a disorganized mass.

FIG. 33.-The 2 daughter cells of the second division widely separated by a split cell plate.

FIG. 34.-The nuclei of 2 fully separated inner daughter cells have divided, thus forming 2 binucleate cells; since both inner cells are to be regarded as megaspores, these 2 binucleate cells are immature female gametophytes.

FIG. 35.-A binucleate embryo sac with no trace of cell membranes.

FIG. 36.-A 4-nucleate stage of the embryo sac.

FIG. 37.-A fully formed embryo sac.

\section{Medeola virginica}

FIG. 38.-A megasporangium showing a single hypodermal megaspore mother cell, in the synaptic stage; magnification but half that of the other figures.

FIG. 39.-The first division of the mother cell; a conspicuous though incomplete cell plate is present.

FIG. 40.- The second division of the mother cell; the cell plate of the first division no longer visible; those of the second division very conspicuous but not sharply defined; the chalazal nuclei are practically equal.

FIG. 4I.-A slightly earlier phase in which the inner pair of nuclei has a small inner (chalazal) nucleus and a large outer nucleus.

FIG. 42.-An embryo sac in which the inner pair of nuclei is very unequal; the inner nucleus stains deeply as though degenerating.

FIG. 43.-The third division; 2 small nuclei and 2 large ones in the antipodal end of the sac as a result of the unequal division of the antipodal nucleus in the previous division; the cell membranes of the second division still visible.

FIG. 44.-Antipodal region of the embryo sac showing 3 equal antipodal cells and the single fusion nucleus, fusion of the polar nuclei having taken place.

\section{Polygonatum commutatum}

FIG. 45.-Two hypodermal mother cells in a single nucellus.

Fig. 46.-A single mother cell showing two layers of cells between it and the epidermis.

FrG. 47.-Two daughter cells of the first division of the mother cell.

Frg. 48.-An axial row of 4 megaspores.

FIG. 49.-The enlarged inner megaspore and the disintegrated remnants of the outer three.

FIG. 50.-First division of the megaspore.

FrG. 51.-Binucleate embryo sac with a single large central vacuole.

FIG. 52.-Mature embryo sac; the polar nuclei not yet fused. 